Document downloaded from:

http://hdl.handle.net/10251/37750

This paper must be cited as:

Maiolini, E.; Ferri, E.; Pitasi, AL.; Montoya Baides, A.; Di Giovanni, M.; Errani, E.; Girotti, S. (2014). Bisphenol A determination in baby bottles by chemiluminescent enzyme-linked immunosorbent assay, lateral flow immunoassay and liquid chromatography tandem mass spectrometry. Analyst. 139(1):318-324. doi:10.1039/c3an00552f.

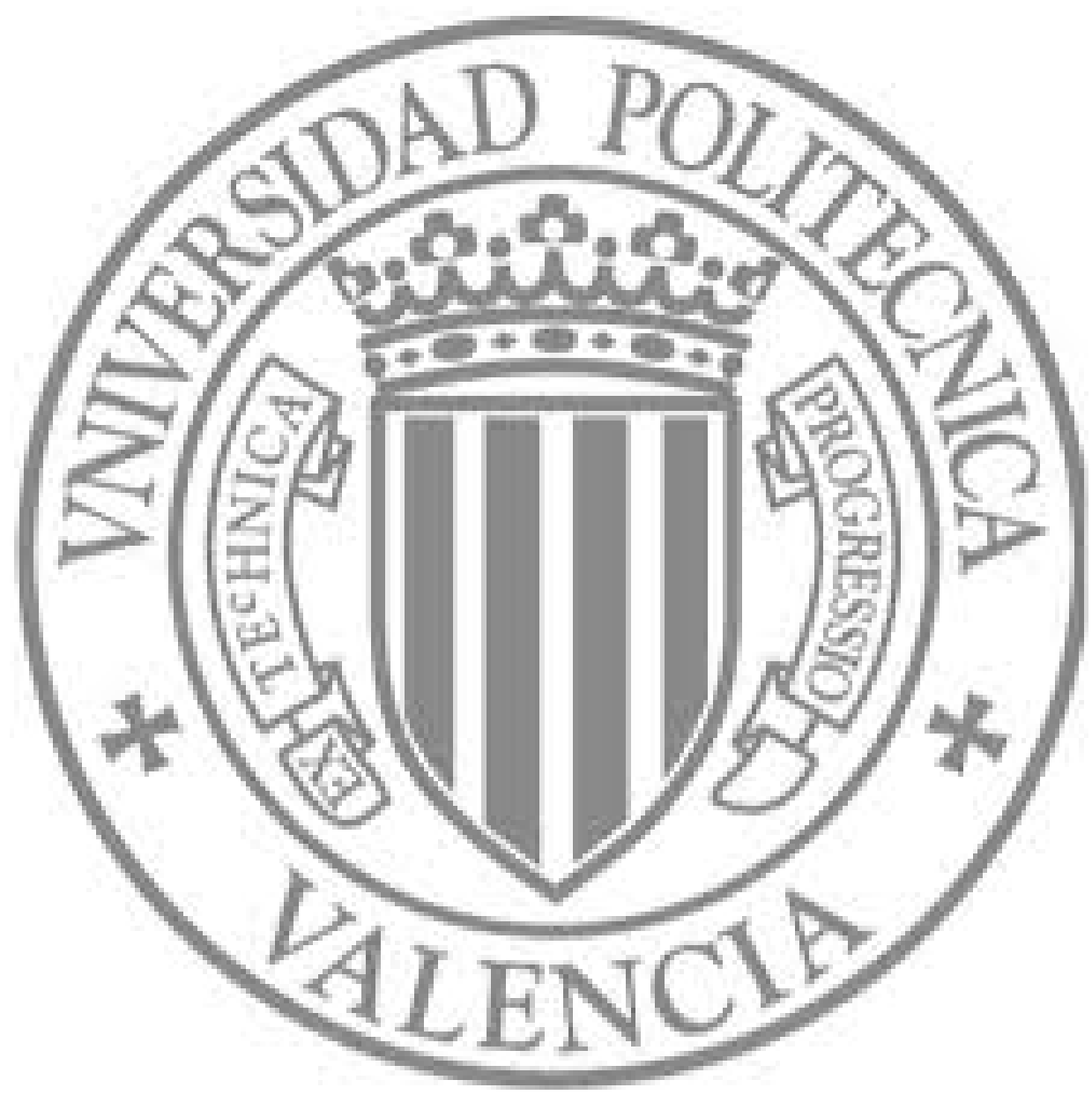

The final publication is available at

Copyright Royal Society of Chemistry 
Cite this: DOI: $10.1039 / \mathrm{c3an} 00552 \mathrm{f}$

Received 20th March 2013

Accepted 19th October 2013

DOI: 10.1039/c3an00552f

www.rsc.org/analyst

\section{Bisphenol A determination in baby bottles by chemiluminescence enzyme-linked immunosorbent assay, lateral flow immunoassay and liquid chromatography tandem mass spectrometry}

\author{
Elisabetta Maiolini, ${ }^{a}$ Elida Ferri, ${ }^{a}$ Agata Laura Pitasi, ${ }^{a}$ Angel Montoya, ${ }^{\mathrm{b}}$ Manuela Di \\ Giovanni, ${ }^{c}$ Ermanno Errani ${ }^{c}$ and Stefano Girotti ${ }^{\star a}$
}

Two immunoassays, a Lateral Flow ImmunoAssay (LFIA) based on colloidal gold nanoparticle labels and an indirect competitive chemiluminescence enzyme-linked immunosorbent assay (CL-ELISA), were developed and a high performance liquid chromatography-tandem mass spectrometry (LC-MS/MS) method was optimized to assess the possible release of bisphenol A (BPA, 4,4'-isopropylidenediphenol) from different plastic baby bottles treated with simulating solutions. Coating conjugate concentration, antiBPA antibody dilution, incubation time of the primary and secondary antibodies, and tolerance to different organic solvents were optimized to obtain the best performance of the ELISA with chemiluminescent end-point detection. The influence of different buffers on LFIA performance was also evaluated. Both methods showed good repeatability (mean CV value around 13\%) and sensitivity. Reproducibility tests for CL-ELISA gave a mean CV value of about $25 \%$. The $\mathrm{IC}_{50}$ and Limit of Detection (LOD) values of CL-ELISA were 0.2 and $0.02 \mathrm{ng} \mathrm{mL}^{-1}$, respectively. The LOD of LFIA was $0.1 \mu \mathrm{gL}^{-1}$. A LC-MS/MS method was also optimized. The separation was performed in a C18 column with a triplequadrupole mass spectrometer with electrospray ionisation interface. The method showed a good linearity in the range 2 to $500 \mathrm{ng} \mathrm{mL}$, with a regression coefficient of 0.998 . In the simulating solutions the detection and quantification limits, calculated by the signal to noise level of $3(S / N=3)$, were $5.8 \mathrm{ng} \mathrm{mL}^{-1}$ and $17.4 \mathrm{ng} \mathrm{mL}^{-1}$, respectively. This limit of quantification was about 3 and 35 times lower than the permitted limits set by the official method CEN/TS $13130-13\left(0.05 \mu \mathrm{g} \mathrm{mL}^{-1}\right)$ and by the Directive 2004/19/EC $\left(0.6 \mu \mathrm{g} \mathrm{mL}^{-1}\right)$, respectively. The methods were applied to determine BPA release from baby bottles, performing repeated procedures according to $E U$ and national regulations. The results demonstrated that no BPA migration from the tested plastic materials occurred with only one exception. The migrated amount, above the regulatory limits, was detected by all the mentioned assays.

\section{Introduction}

Bisphenol A (BPA, 4, $4^{\prime}$-isopropylidenediphenol) is a monomer used primarily in the production of polycarbonate plastics and epoxy resins. ${ }^{1}$ Polycarbonate plastic is used in a wide variety of digital media (e.g., CDs and DVDs) products, electrical and electronic equipment, sport safety equipment, reusable food and drink containers, etc. Epoxy resins are used in engineering applications, in paints and adhesives, and in a variety of protective coatings in metal cans for foods, ${ }^{\mathbf{1}}$ bottle tops, and

${ }^{a}$ Department of Pharmacy and Biotechnology, Alma Mater Studiorum - University of Bologna, Via San Donato 15, 40127 Bologna, Italy. E-mail: stefano.girotti@unibo.it; Web: http://bomet.fci.unibo.it/girotti/; Fax: +39 0512095652; Tel: +390512095660

${ }^{b}$ Inter-University Research Institute for Bioengineering and Human Centered Technology (I3BH), Universitat Politècnica de València, Camino de Vera, s/n, 46022 Valencia, Spain

${ }^{c}$ Regional Agency for Environmental Protection (ARPA), Via F. Rocchi, 19, Bologna, Italy water supply pipes. To a lesser extent BPA is used in the production of polyester resins, polysulfone resins, polyacrylate resins, and flame retardants, in the processing of polyvinyl chloride plastic, and in the recycling of thermal paper.

The primary way of exposure to bisphenol A for most people is assumed to be the diet: BPA in food and beverages accounts for the majority of daily human exposure. ${ }^{1}$ The highest estimated daily intakes of BPA in the general population occur in infants and children and this creates particular concern since BPA has been identified as an important endocrine disrupting compound (EDC). It can interfere with hormonal activities by modification of biosynthesis, metabolism and elimination of natural blood-borne hormones. ${ }^{2}$ Moreover, BPA can originate environmental problems: recent research demonstrates that BPA causes inter-species mating. ${ }^{3}$

The critical period of BPA exposure is during perinatal development, when the effects tend to be permanent due to the 
low binding affinity of BPA to serum protein s $^{4}$ and the capability of xenoestrogenic compounds to bypass the mechanisms that limit the exposure of the baby's organs and brain to circulating estrogens. ${ }^{5}$ It has been reported that exposure to low doses of BPA results in alterations in the ovary, uterus or mammary glands ${ }^{6}$ and produces a decline in reproductive capacity. ${ }^{7}$ These data confirm that during the perinatal period there is an increased sensitivity to BPA with probable consequences for babies' health.

In addition, young children have immature organ systems, high metabolic rates, and relatively low bodyweight, and go through rapid physical development, so repeated exposure to even low levels of BPA may lead to adverse health effects. ${ }^{7}$ Therefore, it is urgently necessary to have effective analytical tools available to carefully evaluate the real levels of exposure to this compound.

The U.S. Food and Drug Administration (FDA) has established a tolerable daily intake (TDI) of $0.05 \mathrm{mg}$ BPA per $\mathrm{kg}$ body weight per day, which is also the reference dose settled by the U.S. Environmental Protection Agency (EPA). On the other hand, a specific migration limit (SML) for BPA of $0.6 \mathrm{mg} \mathrm{kg}$ was set by the EU Commission in $2004 .^{8}$

In September 2010, Canada became the first country in which BPA was banned. ${ }^{9}$ The European Union states outlawed the manufacture of polycarbonate feeding bottles containing the compound from March 2011, and banned their import and sale from June 2011. ${ }^{10}$ This recent BPA banning in baby bottles has forced manufacturers to employ BPA-free plastics. ${ }^{11}$ A recent study by the Joint Research Centre, European Commission, ${ }^{\mathbf{1 2}}$ shows that, unfortunately, possible problems derived from the use of these alternative plastics have not been thoroughly evaluated. ${ }^{13}$

Many methods have been reported with the aim of determining BPA in water and in food: liquid chromatography tandem mass spectrometry, yeast bioassays, immunochemical assays, and HPLC with fluorescence or diode-array detectors. ${ }^{\mathbf{1 4 - 2 3}}$ Immunoassays appear to comply with the sensitivity, rapidity, and low cost requirements for effective monitoring activities. ${ }^{24,25}$

Here we report on the development of a colloidal gold-based lateral flow (LFIA) assay, on the optimization of an ELISA with chemiluminescent detection (CL-ELISA), both based on an indirect competitive immunoreaction, and on the optimization of a High Performance Liquid Chromatography Tandem Mass Spectrometry (LC-MS/MS) method for BPA analysis. The three methods were applied to analyze the possible BPA migration from baby bottles treated to simulate the real, repeated conditions of use, taking into account the food characteristics and the sterilization and heating procedures usually involved. This study was performed according to the statement: "heating bottles or pouring hot liquids into bottles, the presence of acidic or basic foods and beverages have all been shown to increase the rate of BPA leaching from bottles". ${ }^{26}$

\section{Materials and methods}

\subsection{Reagents}

Bisphenol A standard powder (purity $>97.7 \%$ ) and bisphenol A $d^{16}$ (98\% purity), the second one employed in HPLC-MS/MS measurements, were purchased from Acros Organics (Geel, Belgium) and Sigma Aldrich (Milan, Italy), respectively.
Reagents of analytical grade such as glacial acetic acid, ethanol, methanol, ammonia ( $32 \%$ aqueous solution) and sodium hypochlorite (aqueous solution, 7\% active chlorine) were provided by Carlo Erba Reagents (Milan, Italy). Luminol, hydrogen peroxide and $p$-iodophenol were from Sigma Aldrich Srl (Milano, Italy). Ultrapure water was produced in a MilliQ plant (Millipore Corp., Billerica, MA, USA).

The main buffering solutions employed were: $0.05 \mathrm{M}$ carbonate-bicarbonate buffer , pH 9.6; 10 mM PBS , pH 7.4 (10 mM $\left.\mathrm{Na}_{2} \mathrm{HPO}_{4}, 2 \mathrm{mM} \mathrm{KH} \mathrm{PO}_{4}, 137 \mathrm{mM} \mathrm{NaCl}, 2.7 \mathrm{mM} \mathrm{KCl}\right) ;$ PBST (PBS containing 0.05\% Tween20); PBSG 1 (10 mM PBS, 0.5\% Fish Gelatine); PBSG 2 (20 mM PBS, 1\% Fish Gelatine), and 0.2 $\mathrm{M}$ BB (borate buffer: $50 \mathrm{mM} \mathrm{Na}_{2} \mathrm{~B}_{4} \mathrm{O}_{7}, 200 \mathrm{mM} \mathrm{H}_{3} \mathrm{BO}_{3}, \mathrm{pH} 8.5$ ).

\subsection{Immunoreagents}

Mouse anti-bisphenol A monoclonal antibody (BPAB-11) and hapten conjugate, OVA-BPAB, were produced by the Immunotechnology Group at Polytechnic University of Valencia (I3BH, UPV, Spain). Rabbit anti-mouse, goat anti-rabbit immunoglobulins, and tetrachloroauric acid were from Sigma; horseradish peroxidase labelled rabbit anti-mouse immunoglobulin was from Dako (Glostrup, Denmark).

\subsection{Sample treatment}

Twelve polycarbonate (PC) and 12 polypropylene (PP) baby bottles of $260 \mathrm{~mL}$ of capacity were analyzed, the first ones containing BPA and the second ones being BPA free. The analyzed samples were representative of various brands of baby bottles available in the Italian market.

In order to simulate the migration of bisphenol A from baby bottles under different conditions several assays were carried out using liquids simulating different kinds of food, as indicated in the European Commission Directives 93/8/EEC and 97/48/EEC. ${ }^{27,28}$ Three different solutions were used:

- Simulating solution A: distilled water. It reproduced the extraction capability of aqueous food with $\mathrm{pH}>4.5$.

- Simulating solution B: water-acetic acid $97: 3(\mathrm{v} / \mathrm{v})$. It reproduced the extraction capability of acidic food with $\mathrm{pH}<4.5$.

- Simulating solution C: water-ethanol $50: 50$ (v/v). It reproduced the extraction capability of fatty food (particularly milk).

The migration tests were conducted in order to reproduce the conditions of real home-use during the disinfection and meal preparation steps, taking into account the indications reported in the leaflets of the different bottles which recommend a 5 minutes boiling in water prior to the first use. To this end, the bottles of the same material (PP or PC) were divided into two groups of 6 bottles each: one group was subjected to the initial sterilization by 5 minutes boiling whereas the other one was not. Each group of 6 bottles was further divided into two groups of 3 bottles made by the same material and each bottle was filled with one of the simulating solutions $\mathrm{A}, \mathrm{B}$, or $\mathrm{C}$. One group was treated by microwaves and the second one by water bath heating for 6 consecutive cycles, replacing the simulating solutions after every cycle (Fig. 1). Only the simulating liquids obtained after the third and sixth migration cycles were analyzed, as 


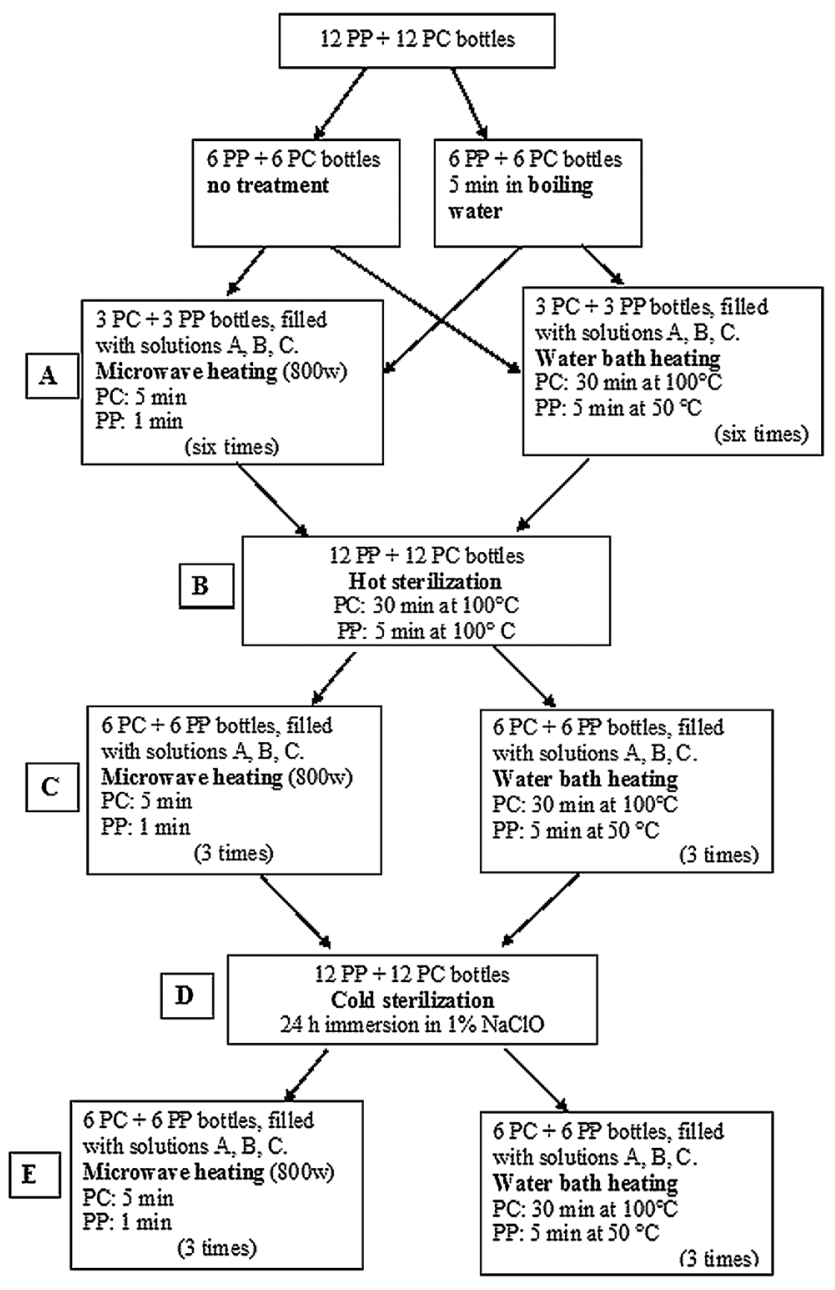

Fig. 1 Scheme of the procedure to induce migration of BPA from baby bottle simulating conditions of repeated use.

indicated by the Italian legislation. ${ }^{29}$ Further tests were carried out under conditions of stress simulated by the two cycles of sterilization, the first one by heat and the second one by cold sterilization. After each sterilization cycle 3 migration cycles in a water bath or microwave oven were applied. Time and temperature exposure conditions complied with the EU legislation ${ }^{27}$ and the instructions for use of each bottle.

2.3.1 Release tests in a water bath. The baby bottles filled to the maximum volume with the different types of food simulants were placed in a water bath conditioned at the working temperature range, according to the Italian regulation requirements ${ }^{29}$ and to the information contained in the leaflet of each bottle.

For polycarbonate bottles (containing BPA): 30 min exposure at $100{ }^{\circ} \mathrm{C}$. For bottles made of PP: 5 min exposure at $50{ }^{\circ} \mathrm{C}$ (Fig. 1, step A, right).

2.3.2 Release tests in a microwave oven. The bottles filled to the maximum volume with the different types of food simulants were placed in a microwave oven at $800 \mathrm{~W}$ for different times according to the indications given in the respective leaflet (Fig. 1, step A, left). The conditions of migration cycles were as follows: for PC bottles: 5 min exposure, for PP bottles: $1 \mathrm{~min}$ exposure.

2.3.3 Release tests after heat sterilization. All the baby bottles already used for migration tests in the water bath or microwave oven were subjected to a process of heat sterilization in boiling water (30 min for PC bottles and $5 \mathrm{~min}$ for PP bottles) (Step B in Fig. 1) and to three further migration tests in the water bath or microwave oven under the conditions previously described (Step C in Fig. 1). Only the simulating liquids of the third release test were analyzed.

2.3.4 Release tests after cold sterilization. Following the migration tests after hot sterilization described above, a cold sterilization treatment was performed by immersion of the baby bottles for 24 hours in $1 \%(\mathrm{w} / \mathrm{w}) \mathrm{NaClO}$ aqueous solution (Step D in Fig. 1). This solution contains a concentration of active chlorine similar to that found in commercial solutions for the disinfection of baby bottles and objects in contact with food. A further series of three migration tests were carried out after the cold sterilization both in the water bath and microwave oven under the usual conditions (Step E in Fig. 1). As before, only the simulating liquids employed in the third cycle were analyzed.

\subsection{Chemiluminescent ELISA}

ELISAs were performed in 96-well microplates in the indirect competitive conjugate-coated format using the OVA-BPAB hapten conjugate and BPAB-11 monoclonal antibody previously employed to develop and validate a colorimetric ELISA. ${ }^{17,25}$ The optimal concentrations for the chemiluminescent assay were first established by checkerboard titration using the same concentration range, $0.05-0.2 \mu \mathrm{g} \mathrm{mL}^{-1}$, for both immunoreagents. In order to obtain the best competitive calibration curve other parameters were again examined such as tolerance to the organic solvents methanol and 1-4 dioxane at 1, 5, and $10 \%$ final proportions, time of the various immunoassay steps, and effect of shaking during the competitive step.

The optimized calibration curves were performed in the $0.001-1000 \mathrm{ng} \mathrm{mL}{ }^{-1}$ range. The OVA-BPAB conjugate $(0.2 \mu \mathrm{g}$ $\left.\mathrm{mL}^{-1}\right)$ in $0.05 \mathrm{M}$ carbonate-bicarbonate buffer, $\mathrm{pH} 9.6(100 \mu \mathrm{L}$ per well) was added into the black polystyrene high-binding microplates (Costar, Cambridge, USA) and incubated overnight at $4{ }^{\circ} \mathrm{C}$ for coating. Plates were washed 3 times with $200 \mu \mathrm{L}$ per well of PBST using a microplate washer (WellWash 4, Labsystem, Finland) and the uncoated sites were blocked by adding $200 \mu \mathrm{L}$ per well of PBSG $1 \times$. The plates were incubated at room temperature (RT) for 60 min with shaking and washed again 3 times as described above. For the competitive reaction $50 \mu \mathrm{L}$ per well of $0.2 \mu \mathrm{g} \mathrm{mL} \mathrm{m}^{-1}$ of BPAB-11 antibody in PBSG $2 \times$ and $50 \mu \mathrm{L}$ per well of standard solution or sample extract were added and incubated for $60 \mathrm{~min}$ at RT without shaking. In order to avoid the absorption of BPA on plastic surfaces only glass containers were used to manipulate the standard solutions (glass vials, Hamilton syringes, etc.). After another microplate washing, $100 \mu \mathrm{L}$ per well of rabbit anti-mouse IgG-HRP diluted $1: 2000$ in PBSG $1 \times$ were added and incubated for $60 \mathrm{~min}$ at RT with shaking. Finally, after a new washing step, $100 \mu \mathrm{L}$ of luminescent mixture $(45 \mu \mathrm{L}$ of $1 \mathrm{mM}$ luminol, $10 \mu \mathrm{L}$ of $0.5 \mathrm{mM} p$-iodophenol, $9.8 \mathrm{~mL}$ of $0.2 \mathrm{M}$ 
borate buffer, $\mathrm{pH} 8.5$ and $100 \mu \mathrm{L}$ of $1 \mathrm{mM}$ hydrogen peroxide) were added to each well and the luminescence emission at $425 \mathrm{~nm}$ was immediately recorded using a Victor 1420 luminometer (Wallac-Perkin Elmer, Waltham, MA, USA) and expressed as Relative Luminescence Units (RLU).

The chemiluminescent emission values $\left(E_{x}\right)$ were normalized between $100 \%$ (the emission of a blank control, $E_{0}$ ) and $0 \%$ (the emission of a sample with an excess of standard compound, $\left.E_{\text {excess }}\right)$ according to the expression:

$$
\% B / B_{0}=100\left(E_{x}-E_{\text {excess }}\right) /\left(E_{0}-E_{\text {excess }}\right)
$$

The results, expressed as " $\% B / B_{0}$ ", were the ratio between $B$, the emission of " $X$ " $\mathrm{ng} \mathrm{mL}^{-1}$ standard solution and $B_{0}$, the emission of a $0 \mathrm{ng} \mathrm{mL}^{-1}$ standard solution. ${ }^{30}$ The normalized values were then mathematically fitted, using the Sigmaplot ${ }^{\circledR}$ software (SPSS) version 8.0, to the four parameter logistic equation:

$$
y=\left\{(A-D) /\left[1+(x / C)^{B}\right]\right\}+D
$$

where $A$ is the asymptotic maximum (chemiluminescence intensity in the absence of analyte, RLUmax), $B$ is the curve slope at the inflection point, $C$ is the $x$ value at the inflection point $\left(\mathrm{IC}_{50}\right.$ value, corresponding to the analyte concentration that reduces RLUmax to $50 \%$ ), and $D$ is the asymptotic minimum (background signal). ${ }^{31}$

\subsection{Lateral flow immunoassay}

2.5.1 Colloidal gold preparation and conjugation with secondary antibody. We obtained gold nanoparticles of $40 \mathrm{~nm}$ according to the Frens method ${ }^{32}$ and their conjugation with rabbit anti-mouse immunoglobulin (secondary antibody) was carried out as already described..$^{33}$ Briefly, after determining the optimal antibody dilution to be used for gold conjugation, the gold-antibody solution was subjected to several centrifugation steps in different buffers. The final pellet was resuspended in $0.2 \mathrm{M}$ borate buffer, $\mathrm{pH} 8.5$ containing 1\% BSA, 2\% sucrose, $0.25 \%$ Tween 20 , and $0.05 \%$ sodium azide, and stored at $4{ }^{\circ} \mathrm{C}$ for several months. All centrifugation steps were carried out at $25000 \times g$ for $30 \mathrm{~min}$ at $10{ }^{\circ} \mathrm{C}$ in a Sorvall RC2-B Superspeed centrifuge (Thermo Fisher Scientific Inc., USA).

2.5.2 Preparation of the strips. A HI-Flow Plus HFB1200225 nitrocellulose membrane strip (Millipore, Billerica, MA, USA) (10 cm length and $2.5 \mathrm{~cm}$ height) was cut and fixed on the Easy Printer LPM02 printer device (Advanced Sensor Systems P. Ltd., India) for the coating of the test and control lines. The test and control lines were coated with $400 \mu \mathrm{g} \mathrm{mL}^{-1}$ of OVA-BPAB (hapten conjugate) in PBS and $200 \mu \mathrm{g} \mathrm{mL}^{-1}$ of goat anti-rabbit immunoglobulin (GAR, tertiary antibody) in PBS, respectively, distributing $1 \mu \mathrm{L} \mathrm{mm}{ }^{-2}$ of solution. The membrane strips were stored overnight at $37^{\circ} \mathrm{C}$ and then cut in pieces of $0.5 \mathrm{~cm}$ width.

2.5.3 Assay procedure. The lateral flow assay was performed by dipping the strip in a glass tube containing $50 \mu \mathrm{L}$ of running buffer (PBS containing 1\% BSA), $10 \mu \mathrm{L}$ of rabbit antimouse-colloidal gold, and $3 \mu \mathrm{L}$ of $0.45 \mu \mathrm{g} \mathrm{mL} \mathrm{m}^{-1}$ mouse anti-BPA antibody. In the upper part of the strip there was a piece of filter paper to foster the complete migration of the liquid throughout the membrane. The appearance after 5-10 minutes of two red lines confirmed the proper development of the assay. When the sample extracts were added into the tube by means of a Hamilton syringe, the presence of BPA was revealed by the decrease, proportional to the analyte concentration in the sample, of the test line colour intensity.

\subsection{Liquid chromatography tandem mass spectrometry assay}

Alliance ${ }^{\circledR} 2695$ High Performance Liquid Chromatography (HPLC) equipment and an Alliance ${ }^{\circledR} 2695$ autosampler (Waters, Milliford, MA, USA), refrigerated at $5{ }^{\circ} \mathrm{C}$, were used for chromatographic analyses, coupled to a triple-quadrupole mass spectrometer (MS/MS) "Quattro Micro" TM API (Waters, Milliford, MA, USA) with an electrospray ionization interface and a nitrogen Generator (Peak Scientific, Germany).

The detection of BPA was carried out by reverse phase chromatography using a Supelco Discovery ${ }^{\circledR}$ C18 $(150 \times 2.1$ $\mathrm{mm}, 5 \mu \mathrm{m}$ ) column from Supelco (Milan, Italy) thermostated at $30{ }^{\circ} \mathrm{C}$, with phase eluent consisting of demineralized water MilliQ (mobile phase A) and a solution of $0.1 \%(\mathrm{v} / \mathrm{v})$ of ammonia in methanol (mobile phase B) at a constant flow of $200 \mu \mathrm{L}$ $\min ^{-1}$. The elution conditions started from a mixture of $90 \%$ of phase A, followed by a linear gradient of $5 \mathrm{~min}$ up to $85 \%$ of phase $\mathrm{B}$, a plateau of $10 \mathrm{~min}$, return to initial conditions in 2 minutes and finally $5 \mathrm{~min}$ of column reconditioning. The injection volume was $50 \mu \mathrm{L}$. The total elution time was $22 \mathrm{~min}$, with a retention time of $11 \mathrm{~min}$ for bisphenol A.

\section{Results and discussion}

\subsection{Optimization of immunochemical methods}

3.1.1 CL-ELISA. The introduction of the chemiluminescent detection in immunoassays usually produces a significant reduction of the required amount of immunoreagents as compared to colorimetric ELISAs. Results of the checkerboard titration showed that the optimal concentrations to be employed for the BPA CL-ELISA were $0.2 \mu \mathrm{g} \mathrm{mL} \mathrm{m}^{-1}$ of both OVA$\mathrm{BPAB}$ conjugate and $\mathrm{BPAB}-11$ antibody. Concerning other tested

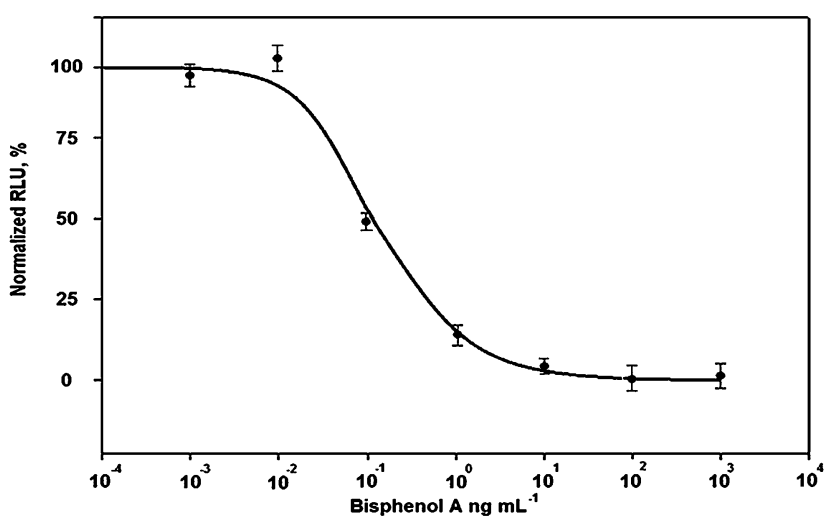

Fig. 2 CL-ELISA calibration curve $(n=3)$ for bisphenol A immunoassay. 
Table 1 Parameters of the MS spectrometer for BPA analysis

\begin{tabular}{|c|c|c|c|c|c|c|c|}
\hline Compound & Ion mode & Cone voltage (V) & Transition quantification & Coll. E (eV) & Transition confirmation & Coll. E (eV) & Dwell (s) \\
\hline BPA & ESI & 31.0 & $227>212$ & 20.0 & $227>133$ & 50.0 & 0.3 \\
\hline $\mathrm{d}^{16}-\mathrm{BPA}$ & ESI & 31.0 & $241>142$ & 20.0 & - & - & 0.3 \\
\hline
\end{tabular}

Table 2 Analytical parameters of the CL-ELISA

\begin{tabular}{llll}
\hline $\begin{array}{l}\text { Standard BPA } \\
\text { conc. }\left(\mathrm{ng} \mathrm{mL} \mathrm{mL}^{-1}\right)\end{array}$ & $\begin{array}{l}\text { Repeatability } \\
\text { CV }(\%)(n=6)\end{array}$ & $\begin{array}{l}\text { Reproducibility } \\
\text { CV }(\%)(n=6)\end{array}$ & $\begin{array}{l}\text { Recovery }(\%) \\
(n=3)\end{array}$ \\
\hline 0.02 & 22.3 & 35.5 & 84.3 \\
0.2 & 15.7 & 28.9 & 86.1 \\
2 & 12.5 & 25.6 & 85.4 \\
7 & 10.6 & 19.8 & 95.6 \\
50 & 9.7 & 22.1 & 91.7 \\
100 & 8.2 & 18.2 & 104.2 \\
\hline
\end{tabular}

parameters the results were in agreement with previous validation tests for the colorimetric ELISA based on the same immunoreagents. ${ }^{25}$ The maximum sensitivity was obtained by using $10 \%$ methanol as the solvent, $60 \mathrm{~min}$ for all incubation steps, and no shaking during the competitive step. Under these conditions useful competitive calibration curves for BPA were

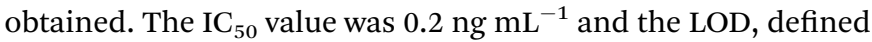
as the lowest BPA concentration exhibiting a $90 \%$ mean luminescence intensity of the zero standard, was equal to $0.02 \mathrm{ng}$ $\mathrm{mL}^{-1}$ (Fig. 2). The performance of the developed CL-ELISA was therefore very close to that previously reported for a colorimetric ELISA in the conjugate-coated format, by employing the same immunoreagents: the colorimetric $\mathrm{IC}_{50}$ and LOD values were 0.3 ng $\mathrm{mL}^{-1}$ and $0.05 \mathrm{ng} \mathrm{mL}^{-1}$, respectively. ${ }^{17}$ Data about the analytical parameters of CL-ELISA are shown in Table 2: mean repeatability $13 \%$, mean reproducibility $25 \%$, and recovery values in the $84-104 \%$ range. The poor reproducibility found (relatively high coefficients of variation) could be explained by the well know problem of BPA absorption to the assay surfaces.

The specificity of monoclonal antibody BPAB-11 had previously been evaluated by performing competitive assays with several compounds structurally related to bisphenol A. ${ }^{17}$ Significant cross reactivity values were observed only with the closely related compounds 4,4-ethylidenebisphenol (6-19\%) and 4-cumylphenol (20-74\%).

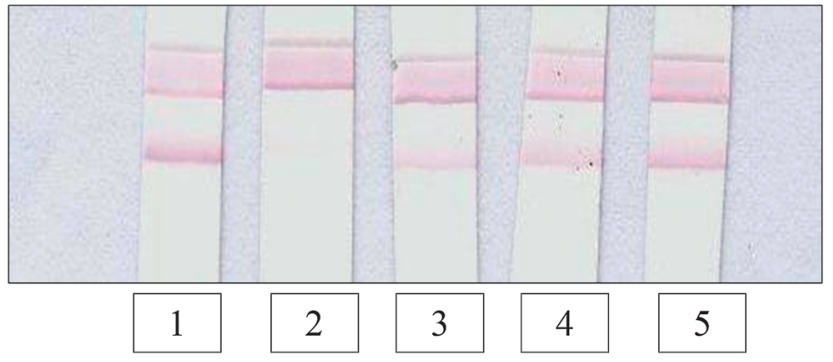

Fig. 3 LFIA for bisphenol A: (1) blank, no bisphenol A; (2) $10 \mu \mathrm{gL}^{-1}$ bisphenol A; (3) $1 \mu \mathrm{g} \mathrm{mL} L^{-1}$ bisphenol A; (4) $0.1 \mu \mathrm{g} \mathrm{mL}^{-1}$ bisphenol A; (5) $0.01 \mu \mathrm{g} \mathrm{mL}^{-1}$ bisphenol A.
3.1.2 LFIA. After the optimization procedures, the best conditions for this assay were $400 \mu \mathrm{L} \mathrm{mL} \mathrm{mL}^{-1}$ of OVA-BPAB (hapten conjugate) in PBS as the test line and $200 \mu \mathrm{L} \mathrm{mL}^{-1}$ of goat anti-rabbit (GAR) antibody in PBS as the control line. To determine the detection limit of the system $1 \mu \mathrm{L}$ of BPA was added to the strip at concentrations in the $0.01-100 \mu \mathrm{g} \mathrm{mL}$ range. The lowest amount providing a visible decrease of the test line intensity was $0.1 \mu \mathrm{g} \mathrm{mL} \mathrm{m}^{-1}$ (no. 4 in Fig. 3). Since this limit was determined visually the lecture of the same LFIA strips was performed by three operators and the limit was defined according to their coincident opinions.

\subsection{Optimization of the LC-MS/MS method}

The optimization of the mass parameters was carried out by separate infusion of a solution of bisphenol A and $\mathrm{d}^{16}$-bisphenol A $1 \mu \mathrm{g} \mathrm{mL} \mathrm{m}^{-1}$ in methanol. The best conditions of ionization were obtained with a potential difference of $3.0 \mathrm{kV}$ to the capillary (capillary voltage), ESI (electron spray ionization) negative mode, a source temperature of $120{ }^{\circ} \mathrm{C}$, a desolvation temperature of $250{ }^{\circ} \mathrm{C}$ and a desolvation gas flow (nitrogen) of $250 \mathrm{~L} \mathrm{~h}^{-1}$.

The quantification transitions chosen were $227>212$ for the bisphenol A (due to the loss of a methyl group ${ }^{34}$ ) and $241>142$ for the deuterated bisphenol A (due to the same molecular rupture), the confirmation transition detected of the bisphenol A was $227>133$ (due to the loss of a phenol group). Table 1 summarizes the setting parameters of the spectrometer and Fig. 4 shows the spectra acquired during scanning in a range from 0 to $400 \mathrm{amu}$ (atomic mass unit) for the identification of the molecular ion $\mathrm{m} / \mathrm{z} 227$ and in a range from 100 to $400 \mathrm{amu}$ for the fragments of transition $\mathrm{m} / \mathrm{z} 212$ and 133 for the bisphenol A and $m / z 142$ for the $\mathrm{d}^{16}$ BPA.

The developed method showed a very good linearity in the 6$500 \mathrm{ng} \mathrm{mL}{ }^{-1}$ range, with a correlation coefficient of 0.998 . The detection limit in the simulating solutions calculated by the signal to noise level of $3(S / N=3)$ was $5.8 \mathrm{ng} \mathrm{mL} \mathrm{mL}^{-1}, 9$ times lower than that stated in the official method UNI CEN/TS 13130-13 [Ref. 35] $\left(0.05 \mu \mathrm{g} \mathrm{mL} \mathrm{m}^{-1}\right)$ and about 100 times lower than the limit set by the 2011/10/EU Directive for the BPA migration in food $\left(0.6 \mu \mathrm{g} \mathrm{mL}{ }^{-1}\right){ }^{8}$ The quantification limit, calculated according to the same criteria $(S / N=10)$, resulted in $17.4 \mathrm{ng}$ $\mathrm{mL}^{-1}$, a value about 3 and 35 times lower, respectively, than the above mentioned permitted limits.

We determined some analytical parameters such as the

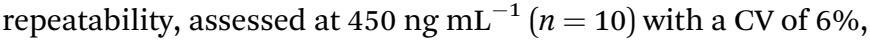
and the reproducibility of a $121 \mathrm{ng} \mathrm{mL}^{-1}$ standard solution $(n=6)$, obtaining in this case a CV of $12.5 \%$. 


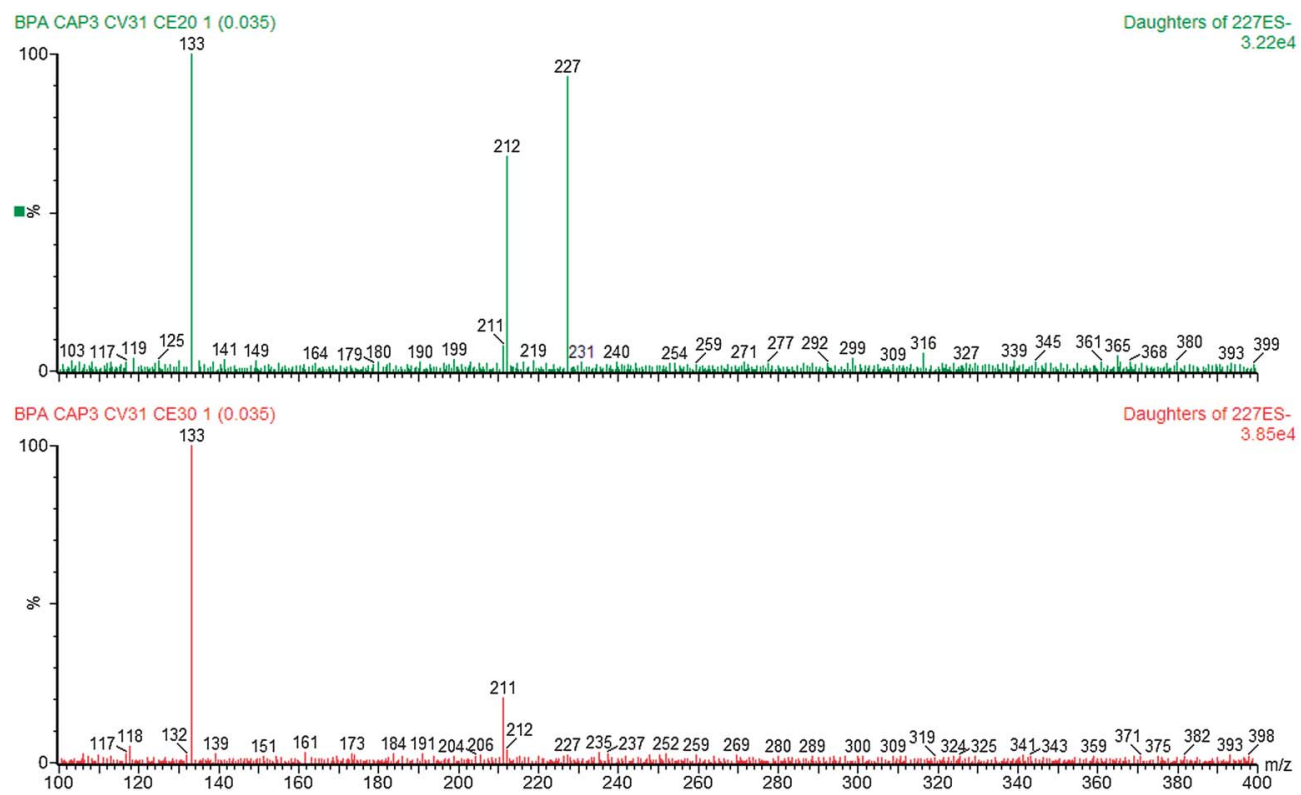

Fig. 4 Spectra acquired during scanning in a range from 0 to $400 \mathrm{amu}$ for the identification of the molecular ion $\mathrm{m} / \mathrm{z} 227$ showing the daughter transition for the bisphenol A $\mathrm{m} / \mathrm{z}$ 133, and 212, raising at $20 \mathrm{eV}$ collision energy.

\subsection{Real sample analysis}

The analysis of simulating samples obtained from migration tests under the different temperature, timing and heating conditions revealed that only one sample resulted clearly positive both in the CL-ELISA and in the LC/MS/MS assay. That sample was the one obtained from the third migration cycle under microwave of the PC bottle filled with the simulant $\mathrm{C}$ and which was not boiled for $5 \mathrm{~min}$ before starting the migration tests. Also the LFIA was applied to the analysis of the simulating liquids and the positive sample gave a clearly positive result, though it was not possible to determine the exact content of BPA. In fact, this rapid method is semi-quantitative and in the case of a positive result the exact concentration should be determined by HPLC-MS/MS, ELISA, or CL-ELISA. The BPA concentrations obtained by the different analytical methods are summarized in Table 3.

All other samples were below the limit of quantification of the quantitative methods and then extensively below the admitted limits set by regulations, showing that the migration of BPA from baby bottles still containing this compound is a quite rare eventuality, even after repeated application of sterilization and heating treatments. Moreover, one sample is not enough to confirm that the 5 min boiling treatment can influence the migration process, at least in the case of subsequent

Table 3 Migrated BPA content in the only one positive sample, as determined by the three methods

\begin{tabular}{lllr}
\hline Method & $\begin{array}{l}\text { BPA content } \\
\left(\mu \mathrm{g} \mathrm{mL} \mathrm{mL}^{-1}\right)\end{array}$ & $\begin{array}{l}\text { Number of } \\
\text { determinations }(n)\end{array}$ & $\begin{array}{r}\text { SD } \\
(\%)\end{array}$ \\
\hline CL-ELISA & 4.5 & 3 & 12.5 \\
LC-MS/MS & 3.3 & 3 & 9.8 \\
LFIA & $+($ up to 1000) & 3 & -
\end{tabular}

treatment by microwave. These results are in accordance with recently reported studies ${ }^{12,13}$ that examined the BPA release from 277 baby bottles made of several types of plastic (polycarbonate, polyamide, polyethersulphone, polypropylene, silicone, and $\operatorname{Tritan}^{\mathrm{TM}}$ ) and purchased from 26 European Union countries, Canada, Switzerland and the USA.

It is surely important to underline that by comparing the data obtained from the LC-MS/MS analysis with those of the two immunoassays not one false positive result from the CL-ELISA or the LFIA was observed, supporting the reliability of these methods.

\section{Conclusion}

The application of the chemiluminescent detection resulted in the optimization of the ELISA, which led to a slight improvement of its sensitivity but also the expected, very useful reduction of the monoclonal antibody and conjugate consumption. The cost per analysis of this sensitive, fast, and high-throughput screening assay is in this way further reduced.

The new, simple and fast LFIA has been revealed to be a very interesting method for the semi-quantitative determination of bisphenol A. The detection limit was very good for such a type of portable assay and the LFIA format was the only one suitable to solve the reproducibility problems of ELISA, connected with the property of BPA to absorb on plastic surfaces: the run can be entirely performed in a glass tube.

Bisphenol A is currently detected by chromatographic separation (LC) often coupled with mass spectrometry. ${ }^{\mathbf{1 4 , 3 4 , 3 6}}$ To ascertain the reliability of the developed immunological methods we set up this simple LC-MS/MS method which was able to determine BPA at concentrations below the lower limits set by the present legal rules and with a LOQ lower than the LC-DAD official method. This LC-MS/MS method does not require any derivatization procedure or pre-concentration step. 
The significant reduction in the time per analysis has been further increased by employing the quicker separation on gradient instead of the isocratic one. The very high sensitivity achieved makes this assay a suitable control method to determine the absolute content of BPA and to reveal the migration of very low amounts of BPA from plastics.

\section{Acknowledgements}

This work was supported by a grant from the University of Bologna (RFO-Focused Fundamental Research Projects 20002011) grants.

\section{References}

1 The Bisphenol-A, http://www.bisphenol-a.org, accessed 04 July 2013.

2 E. Diamanti-Kandarakis, J. P. Bourguignon, C. Giudice, R. Hauser, G. S. Prins, A. M. Soto, R. T. Zoeller and A. C. Gor, Endocr. Rev., 2009, 30, 293-342.

3 J. L. Ward and M. J. Blum, Evol. Appl., 2012, 5, 901-912.

4 S. C. Nagel, F. S. vom Saal and W. V. Welshons, Exp. Biol. Med., 1998, 217, 300-309.

5 N. J. MacLusky and F. Naftolin, Science, 1981, 211, 1294-1303. 6 N. J. Cabaton, P. R. Wadia, B. S. Rubin, D. Zalko, C. M. Schaeberle, M. H. Askenase, J. L. Gadbois, A. P. Tharp, G. S. Whitt, C. Sonnenschein and A. M. Soto, Environ. Health Perspect., 2010, 119, 547-552.

7 M. Munoz-de-Toro, C. Markey, P. R. Wadia, E. H. Luque, B. S. Rubin, C. Sonnenschein and A. M. Soto, Endocrinology, 2005, 146, 4138-4147.

8 Regulation of the European Commission (EU) No. 2011/10/EU of 14 January 2011 relating to materials and articles made of plastic material intended to come into contact with foodstuffs, http://eur-lex.europa.eu/LexUriServ/LexUriServ.do? uri=OJ:L:2011:012:0001:0089:EN:PDF, accessed 04 July 2013.

9 Canada Gazette Part II 144(21): 1806-18, 13 October 2010, http://www.gazette.gc.ca/rp-pr/p2/2010/2010-10-13/pdf/g214421.pdf, accessed 04 July 2013.

10 Commission Directive 2011/8/EU of 28 January 2011 amending Directive 2002/72/EC, Off. J. Eur. Communities: Legis., 2011, 026, 11-14.

11 F. Baldi and A. Mantovani, Baby bottle: Struggling for safety, Food and Veterinary Toxicology Unit - ISS, http://www.iss.it/ $\mathrm{prvn} / \mathrm{focu} /$ cont.php? $\mathrm{id}=281$ \&lang $=2 \& \mathrm{tipo}=42$, accessed 04 July 2013.

12 K. Aschberger, P. Castello, E. Hoekstra, S. Karakitsios, S. Munn, S. Pakalin and D. Sarigiannis, European Commission Joint Research Centre Institute for Health and Consumer Protection, http://publications.jrc.ec.europa.eu/ repository/bitstream/111111111/14221/1/eur\%2024389_bpa $\% 20 \% 20$ baby\%20bottles_chall\%20\%20persp $\% 20 \% 282 \%$ 29.pdf, accessed 04 July 2013.

13 C. Simoneau, S. Valzacchi, V. Morkunas and L. Van den Eede, Food Addit. Contam., 2011, 28, 1763-1768.

14 A. Ballesteros-Gómez, S. Rubio and D. Pérez-Bendito, J. Chromatogr., A, 2009, 1216, 449-469.
15 Y. Feng, B. Ning, P. Su, H. Wang, C. Wang, F. Chen and Z. Gao, Talanta, 2009, 80, 803-808.

16 M. K. Mudiam, R. Jain, V. K. Dua, A. K. Singh, V. P. Sharma and R. C. Murthy, Anal. Bioanal. Chem., 2011, 401, 1695-1701.

17 M. J. Moreno, P. d'Arienzo, J. J. Manclús and A. Montoya, J. Environ. Sci. Health, Part A, 2011, 46, 509-517.

18 G. O. Noonan, L. K. Ackerman and T. H. Begley, J. Agric. Food Chem., 2011, 59, 7178-7185.

19 A. Schecter, N. Malik, D. Haffner, S. Smith, T. R. Harris, O. Paepke and L. Birnbaum, Environ. Sci. Technol., 2010, 44, 9425-9430.

20 L. Viganò, E. Benfenati, A. van Cauwenberge, J. K. Eidem, C. Erratico, A. Goksøyr, W. Kloas, S. Maggioni, A. Mandich and R. Urbatzka, Chemosphere, 2008, 73, 1078-1089.

21 H. Fukata, H. Miyagawa, N. Yamazaki and C. Mori, Toxicol. Mech. Methods, 2006, 16, 427-430.

22 M. Razee, Y. Yamini, S. Shariati, A. Esrafili and M. Shamsipur, J. Chromatogr., A, 2009, 1216, 1511-1514.

23 X. Liu, Y. Yongsheng Ji, H. Zhang and M. Liu, Food Addit. Contam., Part A, 2008, 25, 772-778.

24 M. Farré, L. Kantiania and D. Barceló, Trends Anal. Chem., 2007, 26, 1100-1112.

25 J. J. Manclùs, M. J. Moreno and A. Montoya, Anal. Methods, 2013, 5, 4244-4251.

26 R. L. Gibson, Toxic Baby bottles: Scientific study finds leaching chemicals in clear plastic baby bottles, Environmental California Research \& Policy Center, 2007, http://www.drldiego.com/docs/publications/Toxic_Baby_ Bottles_sm.pdf, accessed 04 July 2013.

27 Commission Directive 93/8/EEC of 15 March 1993, Off. J. Eur. Communities: Legis., 1993, 90, 22-25.

28 Directive 97/48/EC of 27 July 1997, Off. J. Eur. Communities: Legis., 1997, 222, 10-13.

29 Decreto Ministeriale 21/03/1973, Gazzetta Ufficiale, Supplemento Ordinario 104, 20/04/1973.

30 S. Girotti, E. Maiolini, S. Ghini, E. Ferri, F. Fini, P. Nodet and S. Eremin, Anal. Lett., 2008, 41, 46-55.

31 A. E. Botchkareva, S. A. Eremin, A. Montoya, J. J. Manclùs, B. Mickova, P. Rauch, F. Fini and S. Girotti, J. Immunol. Methods, 2003, 283, 45-57.

32 G. Frens, Nature, Phys. Sci., 1973, 241, 20-22.

33 S. Girotti, A. Montoya, S. Eremin, M. J. Moreno, P. Caputo, M. D'Elia, L. Ripani, F. S. Romolo and E. Maiolini, Anal. Bioanal. Chem., 2010, 396, 687-695.

34 M. I. Santillana, E. Ruiz, M. T. Nieto, J. Bustos, J. Maia, R. Sendón and J. J. Sánchez, Food Addit. Contam., Part A, 2011, 28(11), 1610-1618.

35 Materials and articles in contact with foodstuffs - Plastics substances subject to limitation - Part 13: Determination of 2,2-bis(4-hydroxyphenyl)propane (bisphenol A) in food simulants UNI CEN/TS 13130-13:2005, http:/www.cen.eu/ CEN/Sectors/TechnicalCommitteesWorkshops/CENTechnical Committees/Pages/Standards.aspx?param $=6175 \&$ title $=\mathrm{CEN} /$ TC+194, accessed 04 July 2013.

36 N. C. Maragou, A. Makri, E. N. Lampi, N. S. Thomaidis and M. A. Koupparis, Food Addit. Contam., Part A, 2008, 25, 373-383. 